\title{
PEMIKIRAN AL-GHAZALI TENTANG GANJARAN DAN HUKUMAN DALAM PENDIDIKAN ANAK
}

\author{
Jajang Aisyul Muzakki \\ Institut Agama Islam Negeri (IAIN) Syekh Nurjati Cirebon \\ E-mail: abnazmuzakki75@yahoo.co.id
}

Article received: 10 Januari 2017 Review process: 21 Februari 2017

Article published: 28 Februari 2017

\begin{abstract}
Abstrak
Masih banyak kalangan pendidik ataupun lembaga pendidikan yang bersikap kejam terhadap anak didik yang melakukan kesalahan kecil. Seorang guru atau pendidik dituntut untuk melakukan yang terbaik bagi peserta didiknya, termasuk dalam pemberian ganjaran dan hukuman. Imam al-Ghazali di dalam banyak kitabnya, terutama dalam kiotab Ihya 'Ulumuddin sering membahas nilai-nilai pendidikan termasuk pemberian ganjaran dan hukuman kepada peserta didik. Pemikiran al-Ghazali tentang bentuk ganjaran meliputi tiga hal, yaitu : Penghargaan, pujian dan hadiah. Sedangkan terkait hukuman alGhazali tidak sependapat dengan pemberian hukuman langsung pada anak didik, melainkan dengan proses secara bertahap dan berhati-hati. Keduanya (ganjaran dan hukuman) dalam pendidikan dapat dijadikan alat motivasi ekstrinsik terhadap belajaranak. Pendidikan karakter pada anak usia dini dewasa ini sangat diperlukan dikarenakan saat ini Bangsa Indonesia sedang mengalami krisis karakter dalam diri anak bangsa. Karakter disini adalah watak, tabiat, atau kepribadian seseorang yang terbentuk dari hasil internalisasi berbagai kebajikan yang diyakini dan digunakan sebagai landasan untuk cara pandang, berpikir, bersikap dan bertindak. Membangun karakter terhadap anak merupakan tindakan menjadikan seorang anak terbiasa untuk berperilaku baik, sehingga ia menjadi terbiasa. Penelitian ini bertujuan untuk mengetahui bagaimana pendidikan karakter disiplin yang telah berjalan selama ini, baik dari segi perencanaannya, proses pembelajaran, penilaian dan faktor pendukung serta penghambat dalam pendidikan karakter disiplin anak usia dini.
\end{abstract}

\section{Kata Kunci: Pemikiran Al-Gazali, Ganjaran, Hukuman}

\section{A. PENDAHULUAN}

Pendidikan adalah salah satu bentuk interaksi manusia, sekaligus tindakan sosial yang dimungkinkan berlaku melalui suatu jaringan hubungan-hubungan kemanusiaan yang mampu menentukan watak pendidikan dalam suatu masyarakat melalui peranan-peranan individu di dalamnya, yang diterapkan melalui proses pembelajaran.

Dalam proses pembelajaran diperlukan metode belajar mengajar yang efektif dan terarah, karena berhasil tidaknya pencapaian tujuan pendidikan tergantung bagaimana proses belajar yang dialami oleh peserta didik. Peran aktif guru (tenaga didik) dalam hal ini diperlukan untuk mempengaruhi karakteristik kognitif, afektif maupun psikomotorik siswa, dengan memberi 
dorongan moral, membimbing dan memberi fasilitas belajar terbaik melalui metode pembelajaran.

Di antara metode yang umum dipakai dalam proses belajar mengajar adalah dengan menggunakan pendekatan ganjaran dan hukuman terhadap siswa, dengan harapan melalui ganjaran, anak didik semakin merasa dihargai dan bertambah semangatnya untuk melakukan yang lebih baik lagi. Sedangkan hukuman kiranya dapat mencegah berbagai pelanggaran terhadap peraturan, atau sebagai tindakan peringatan keras yang sepenuhnya muncul dari rasa takut terhadap ancaman hukuman.

Hukuman merupakan salah satu instrumen pengukuran pendidikan bagi kualitas fungsional edukatif siswa yang bermasalah maupun berprestasi. Hukuman adalah vaksinasi dini dalam konteks mendidik yang layak diberikan kepada mereka yang bermasalah.

Jika ada orang yang mengatakan, bahwa hukuman tidak relevan lagi diaplikasikan dalam era modern ini, dan keberhasilan belajar anak oleh faktor tersebut, maka pernyataan tersebut tidak selamanya benar. Sebab dalam batas-batas tertentu hukuman mempunyai makna yang sangat penting. Memberikan hukuman bukanlah hal yang gampang, seperti melempar batu ke dalam air, tetapi ada teknik dan cara tertentu agar siswa tetap merasa aman.

Masih banyak kalangan pendidik ataupun lembaga pendidikan yang bersikap kejam terhadap anak didik yang melakukan kesalahan kecil. Terkadang hanya karena lupa membawa buku pelajaran atau tidak bisa menjawab soal, maka anak didik langsung dipukul dan dicacimaki. Tindakan seperti itu masih bisa ditemukan di lembaga-lembaga pendidikan. Begitu juga prestasi yang diraih anak didik kurang mendapatkan perhatian dari para pendidik. Masih ada pendidik yang tidak memebrikan ganjaran atau penghargaan terhadap presatasi yang dicapai anak didiknya. Akhirnya sang anak merasa tidak diperhatikan dan dihargai oleh pendidiknya sendiri.Dia pun tidak bersemangat untuk meraih prestasi berikutnya. Padahal sesungguhnya ganjaran dan hukuman sebagai salah satu alat pendidikan yang bersifat represif memiliki makna yang sangat dalam. Bila seorang guru mengobral ganjaran dan hukuman, maka akan menimbulkan ekses negatif bagi siswa.

Guru tidak ubahnya seperti seorang dokter yang harus memahami pasiennya. Bila dokter mengobati seluruh pasiennya dengan satu macam obat saja, tentu banyak dari mereka yang akan mati. Begitu pula jika seorang guru membawakan satu macam obat, sistem, dan latihan kepada 
seluruh muridnya, tentu banyak pula dari mereka yang akan rusak dan mati jiwanya serta tumpul semangat berpikirnya.

Seorang guru dituntut untuk memberikan yang terbaik bagi peserta didiknya, termasuk pemberian ganjaran dan hukuman. Jangan sampai ketika dia memberikan ganjaran kepada murudnya dinilai sebagai upah, begitu juga hukuman yang diberikannya dirasakan sebagai siksaan. Kedua alat pendidikan ini mempunyai prinsip yang kontradiktif. Hukuman merupakan sesuatu yang tidak menyenangkan sebagai imbalan dari perbuatan yang tidak baik. Sedangkan ganjaran merupakan sesuatu yang menyenangkan sebagai imbalan dari perbuatan baik yang dilakukan anak didik. Akan tetapi perlu diingat bahwa dalam pemberian ganjaran dan hukuman, seorang guru harus memiliki motivasi agar hukuman yang diberikan kepada peserta didik bisa menjadi motif yang baik bagi peserta didik tersebut.

Walaupun sudah berlalu hampir seribu tahun, namun pemikiran Imam al-Ghozali dalam pendidikan masih sangat bernilai dan mengandung nilai-nilai pendidikan yang relevan dengan zaman sekarang. Salah satu diantaranya adalah pendangan beliau tentang urgensi pemberian motivasi terhadapa peserta didik, baik berupa hadiah ataupun hukuman.

Imam al-Ghozali di dalam banyak kitabnya, sering membahas nilai-nilai pendidikan termasuk pemberian ganajaran dan hukuman kepada peserta didik. Di dalam kitab Ihya 'Ulumiddiin, dengan kedalaman ilmunya beliau mengupas makna, hikmah, dan nilai pendidikan yang terkandung dalam pemberian ganjaran dan hukuman.

Oleh karena itu, perlu adanya kajian dan analisa terhadap pemikiran Imam al-Ghozali seputar pemebrian ganjaran dan hukuman dalam pendidikan, sehingga pemikiran-pemikiran beliau bisa diaplikasikan di semua lem,baga pendidikan, khususnya lembaga pendidikan Islam.

\section{B. Mengenal Sosok Imam al-Ghozali}

Nama lengkapnya adalah Abu Hamid Muhammad bin Muhammad at-Tusi Al-Ghazali. Lahir pada tahun $450 \mathrm{H}$ / 1058 M, di sebuah desa kecil bernama Ghazalah Thabaran, bagian dari kota Tus (sekarang dekat Meshed) wilayah khurasan (Iran). Nama Al-Ghazali kadang-kadang diucapkan Al-Ghazali, kata ini berasal dari Ghazzal, artinya tukang pintal benang, karena pekerjaan ayahnya Al-Ghazali adalah meminta benang wol. Sedangkan kata Al-Ghazali diambil dari kata ghazalah, nama kampung kelahiran Al-Ghazali. Ayah Al-Ghazali adalah seorang tasawuf yang saleh. Ia meninggal dunia ketika Al-Ghazali beserta saudaranya masih kecil. 
Al-Ghazali pertama belajar ilmu agama di kota Thus. Kemudian meneruskan di Jurjan dan akhirnya di naisabut dan belajar pada Imam Al- Juwaini, karena kecerdasan dan kemaunya, kemudian Al- Juwaini memberi gelar "Bahrun Mughriq" yaitu laut yang menenggelamkan. Kemudian ia berkunjung kepada Nidzam Al-Mulk di kota Mu'asar dan ia mendapat kehormatan dan penghargaan yang besar (professor) pada perguruan tinggi Nizamiyah yang berada di kota Baghdad.

Pada tahun $488 \mathrm{H}$, Al-Ghazali pergi ke Mekkah untuk menunaikan ibadah haji dan melanjutkan perjalanan ke Damaskus untuk menetap beberapa lama dan beribadah di Masjid alUmawi. Pada saat itulah ia sempat mengarang kitab Ihya Ulumuddin. Beliau wafat pada tanggal 14 Jumadil Akhir tahun $505 \mathrm{H} / 18$ Desember $1111 \mathrm{M}$ dalam usia \pm 55 tahun, di desa Tabaran dekat Tus.

Karya-karya Al-Ghazali tidak kurang dari 70 karya-karya yang meliputi ilmu pengetahuan, beberapa di antaranya sebagai berikut : Sumbangan terbesar Al-Ghazali adalah Ihya Ulumuddin. Dalam analisa mengenai masalah-masalah penting agama, dan mengenai ilmu pengetahuan, buku ini merupakan salah satu maha karya dunia. Beberapa Sufi memandangnya sebagai buku terbaik setelah Al-Qur'an dan hadits.

\section{Dasar-dasar Pemikiran al-Ghozali tentang Ganjaran dan Hukuman.}

Di antara metode pendidikan dalam islam adalah metode pemberian ganjaran dan hukuman. Pemberian ganjaran dan hukuman adalah sesuatu yang disyariatkan dan termasuk salah satu sarana pendidikan yang berhasil yang sesekali mungkin diperlukan pendidik. Ganjaran dan hukuman dalam pendidikan berfungsi sebagai alat pendorong untuk meningkatkan belajar anak didik. Ganjaran sebagai imbalan dari perbuatan baik, sedangkan hukuman merupakan imbalan dari perbuatan yang tidak baik. Dalam Al-Qur'an disebutkan yang Artinya: "Barangsiapa yang mengerjakan kebaikan seberat dzarrahpun, niscaya dia akan melihat (balasan)nya. Dan barangsiapa yang mengerjakan kejahatan sebesar dzarrahpun, niscaya Dia akan melihat (balasan)nya pula. (QS. al-Zalzalah : 7-8)

Ayat di atas mejelaskan bahwa setiap orang yang melakukan kebaikan pasti akan mendapatkan ganjarannya, demikian juga orang yang melakukan kejelekan maka dia akan mendapatkan hukumannya.

Di lembaga pendidikan, ganjaran diberikan kepada anak didik yang telah menampakkan hasil yang baik, dan hukuman diberikan kepada anak didik yang tidak telah melakukan 
kejahatan seperti melanggar peraturan atau tata tertib madrasah/sekolah. Mengenai pemberian ganjaran dan hukuman, al-Ghozali menempatkannya dalam proporsi yang wajar. Jika anak didik melakukan kesalahan, maka pendidik tidak diperkenankan menggunakan kata-kata kasar, sebab menjadikan tujuan hukuman tidak akan berhasil, bahkan sebaliknya. Beliau berkata :

“Jangan sekali-kali menggunakan kata-kata kasar sebab yang demikian itu sebenarnya dapat menusuk ulu hati, lebih sakit dari tikaman pedang, bahkan lebih melukai dari pada lemparan panah atau pukulan dengan lembing yang panjang. Sedangkan maksud dari hukuman tidak tercapai, faidah tidak didapat, dan membuat ia lari dari sisi kalian”.

Menurut al-Ghozali mendidik anak harus disesuaikan dengan fitrah dan diserasikan dengan naluriahnya, karena pada prinsipnya anak-anak diciptakan Allah dengan fitrah yang dapat menerima kebaikan dan kejahatan. Setiap pendidik tidak terburu-buru menjatuhkan hukuman terhadap anak didik yang bersalah. Jika memang perlu, maka pendidik menggunakannya dengan jalinan kasih sayang. ${ }^{1}$

Dalam satu hadits yang diriwayatkan oleh Abu Hurairah r.a. Rasulullah saw bersabda :

$$
\text { ما من مولود إلا يولد على الفطرة فأبواه يهودانه أو ينصر انه أو يمجسانه ( رواه البخاري في كتاب الجنائز - باب إذا أسلم }
$$

Artinya : Tidaklah seorang anak kecuali dilahirkan dalam kondisi atau keadaan fitrah (kesucian Islam). Maka orang tuanyalah yang menjadikannya Yahudi, atau Nasrani, atau Majusi. ( HR. Al-Bukhāri).

Hadits tersebut menjelaskan bahwa orang tua bertanggung jawab atas masa depan anak dan keluarga. Apakah anak dan keluarganya menjadi orang islam atau kafir. Setiap anak yang dilahirkan ke dunia dalam keadaan fitrah, yaitu dalam kesucian iman dan islam. Namun perkembangan anak dipengaruhi oleh bimbingan dan didikan orang tua dalam lingkungan keluarga. Maka bimbingan dan didikan orang tuanyalah yang akan menentukan hari depannya. Apakah ia menjadi Yahudi, Nasrani, atau Majusi. Jika orang tuanya tidak membimbing dan mendidik keimanan dan keislamannya, ia menjadi orang yang tidak beriman yang dapat mengakibatkan orang tuanya mendapat siksaan dari Allah. Padahal telah diperingatkan dalam firman-Nya Artinya : "Hai orang-orang yang beriman, peliharalah dirimu dan keluargamu dari api neraka yang bahan bakarnya adalah manusia dan batu; penjaganya malaikat-malaikat yang 
kasar, keras, dan tidak mendurhakai Allah terhadap apa yang diperintahkan-Nya kepada mereka dan selalu mengerjakan apa yang diperintahkan”. (QS. At-Tahrim : 6 ).

\section{Pemikiran-pemikiran Imam al-Ghozali tentang Ganjaran dan Hukuman.}

Ganjaran merupakan suatu alat pendidikan yang diberikan kepada anak didik sebagai imbalan terhadap prestasi yang dicapainya. Al-Ghazali berpendapat bahwa jika suatu saat ada seorang anak yang menunjukkan tingkah laku yang terpuji, maka mereka harus dihargai dengan membalasnya yaitu dengan pujian sebagai hadiah.

Al-Ghazali membagi tiga macam ganjaran, yaitu :

1. Penghormatan (penghargaan), baik berupa kata-kata maupun isyarat. Penghormatan dengan kata-kata misalkan : baik, bagi, pintar. Sedangkan penghormatan dengan isyarat dapat berupa anggukan kepala dengan wajah berseri-seri, menunjukkan jempol, tepuk tangan ataupun menepuk bahu.

2. Hadiah yaitu ganjaran yang dapat berupa pemberian suatu yang berbentuk materi dengan tujuan untuk menggembirakan anak didik. Untuk pemberian hadiah berupa materi tidak perlu berupa barang yang mewah tetapi daya guna barang tersebut. Selain itu, pemberian hadiah materi jangan sering dilakukan tetapi hanya dapat dilakukan pada situasi dan kondisi tertentu saja.

3. Pujian dihadapan orang banyak, Ganjaran yang berbentuk pujian dapat juga diberikan dihadapan orang banyak, misalkan teman sekelasnya ataupun orang tua dari anak didik yang bersangkutan ketika penerimaan raport.

Ganjaran berfungsi sebagai reinforcement atau penguatan untuk memotivasi anak didik agar meningkatkan prestasi dan atau tingkah laku yang terpuji. Tentang pemberian hukuman, AlGhazali tidak sependapat dengan pemberian hukuman pada anak didik. Beliau menjelaskan bahwa pemberian hukuman harus melalui proses yaitu : jika ada seorang anak didik yang berperilaku menyimpang, maka seorang guru maupun orang tua memberikan hukuman melalui tiga tahapan, yaitu tahap pertama : apabila anak didik melakukan kesalahan, maka sebagai gurunya harus memberikan kesempatan pada anak didik untuk memperbaiki diri. Dalam hal ini, anak didik diharapkan mampu menyadari kesalahan yang diperbuatnya sehingga menjadikannya untuk tidak mengulanginya lagi.Jika pada tahap pertama, anak didik belum bisa memperbaikinya, maka dilakukan tahap kedua yaitu dengan memberi teguran, kritikan atau celaan. Dan ketika menegur, mengeritik ataupun mencela anak didik tidak diperkenankan 
dilakukan di depan umum. Hal tersebut dikhawatirkan dapat menimbulkan rasa malu.Teguran yang diberikan pada anak didik harus singkat dan bijaksana, apabila tahap kedua telah dilakukan, tetapi anak didik belum bisa memperbaikinya, maka dilakukan tahap ketiga yaitu pemberian hukuman. Hukuman yang dimaksudkan adalah hukuman fisik. Hukuman ini tidak boleh menimbulkan penderitaan bagi anak didik. Dan jika memungkinkan maka hukuman yang diberikan harus ringan.

Al-Ghazali mengibaratkan guru atau pendidik sebagai seorang dokter yang harus mengetahui jenis penyakit yang diderita oleh pasiennya. Dan segera memberikan obat yang sesuai dengan penyakit oleh pasiennya.

Begitu pula guru harus mampu memberi solusi yang terbaik apabila terjadi perilaku yang menyimpang. Guru harus mampu menyesuaikan kesalahan anak didik dengan hukuman yang akan diterimanya.Dalam kitab Ihya Ulumuddin, al-Ghazali menjelaskan bahwa salah satu kewajiban seorang guru adalah berusaha mencegah anak didiknya dari perbuatan yang tidak baik dengan penuh kehati-hatian dan dengan cara sendirian. Tetapi tidak dengan cara kekerasan, karena dapat mengakibatkan anak didik menjadi lebih ${ }^{2}$ berani dan tidak patuh lagi kepada gurunya.

Al-Ghazali berpendapat bahwa fitrah manusia adalah baik, tetapi hal tersebut tidak menjamin bahwa manusia akan selalu berbuat kebaikan. Karena manusia terdiri dari kebaikan dan watak yang merupakan dua badan satu nyawa yang tidak bisa dipisahkan.

\section{E. Beberapa Pengaruh dari Pemikiran al-Ghozali}

Ada beberapa pengaruh yang perlu diperhatikan dari pemikiran-pemikiran al-Ghozali di atas, yaitu :

Pertama, Ganjaran dan hukuman harus diberikan kepada anak yang perlu menerimanya, sehingga tujuan pemberian ganjaran dan hukuman sesuai dengan yang diinginkan. Memang dalam pemberian ganjaran dan hukuman tidak ada buku resepnya, dalam arti berhasil baik atau tidak suatu ganjaran atau hukuman tergantung kepada pribadi si pendidik, anak didik, dan bahan atau cara yang dipakai dalam mengajar atau menghukum anak didik.

Kedua, Guru merupakan faktor utama dalam pendidikan. Keberhasilan suatu pendidikan diantaranya tergantung kepada si pendidik. Selain itu guru atau pendidik juga merupakan wakil

2. Al-Ghazāli, Ihyā 'Ulūm ad-Dīn, (Beirut : Dār Ihyā Al-Turāts, 1990), Jilid. 3, h. 107 
penuh dari orang tua anak didik di sekolah untuk mengemban pembinaan dan pengetahuan tingkah lakunya. Dalam hal ini al-Ghozali mengatakan :

$$
\text { حقّ المعلّم أعظم من حقّ الو الدين فإن الو الد سبب الوجود الحاضر و الحباة الفانية و المعلّم سبب الحياة الباقية }
$$

Artinya : Hak guru itu lebih besar daripada hak orang tua, karena kedua orang tua merupakan penyebab keberadaan (anak) sekarang di dunia dan di kehidupan yang fana, sedangkan guru penyebab keberadaan (anak) di kehidupan yang abadi.

Dengan demikian, bila seorang guru mengobral pujian, maka akan menjadikan anak selalu berharap pada sanjungan atau pujian. Jika ini terjadi maka guru akan merasa kesulitan untuk menerapkan atau menyampaikan materi pelajaran. Si anak tidak akan mau menulis atau menedengarkan keterangan gurunya, sehingga guru tersebut akhirnya menuruti keinginannya. Dengan demikian tujuan pembelajaran akan terganggu. Di satu sisi guru harus menyampaikan materi pelajaran, sementara di sisi lain guru harus memperhatikan anak didik yang suka dipuji. Oleh karena itu pujian diberikan kepada anak didik yang bisa meningkatkan prestasinya dalam belajar. Di lembaga pendidikan kiranya sudah berjalan agar memperhatikan keunggulan anak didik yang rajin dan cerdas dengan diberikan penghargaan moril, sebagaimana digambarkan oleh Ahmad Syalabi :"Jika anak memperlihatkan keunggulan dan kecerdasannya, maka dia dinaikkan ke atas kuda atau unta setelah diberikan pakaian sebagus-bagusnya dan diiiringi oleh saudara-saudara dan handai taulan".

Ketiga, Pendidik dalam memberikan ganjaran yang berupa penghargaan ini agar tidak menyebabkan reaksi negatif dari siswa yang lain. Untuk itu pendidik agar mempertimbangkannya secara matang dan selektif, sehingga pemberian penghargaan akan menimbulkan motivasi anak didik untuk berbuat yang lebih baik lagi.

Keempat, Hadiah-hadiah yang diberikan kepada anak didik sebagai imbalan dari keunggulan prestasi-prestasinya dalam pendidikan, maka pemberiannya jangan sampai menimbulkan pemahaman bahwa hadiah tersebut sebagai upah dari hasil jerih payah anak didik. Jika nilai ganjaran sudah dianggap sebagai upah atau sesuatu yang mempunyai nilai ganti rugi dari suatu pekerjaan atau jasa, maka tujuan anak bukan lagi mencari ilmu pengetahuan melainkan mencari upah.

Kelima, Jika proses belajar mengajar ingin berhasil, maka setiap pendidik harus memikirkan setiap anak dan memeberikan hukuman yang sesuai setelah dipertimbangkan kesalahan ayang dilakukan anak didiknya. Pendidik juga jangan terlalu mudah memberikan maaf 
kepada anak didik yang melanggar, sebab ia akan merasa keenakan dan asyik dengan pelanggaran-pelanggarannya. Pendidik harus meluruskan kesalahan-kesalahan anak didiknya dengan pendekatan yang lemah lembut. Ia harus menghukum anak didiknya sebagai koreksi atas tingkah laku yang salah, dan memberikan hadiah sebagai pendorong agar anak didik lebih giat belajarnya.

Keenam, Guru dan murid merupakan kesatuan yang tidak bisa dipisahkan dalam pendidikan. Guru sebagai subyek atau penyampai materi pelajaran, dan murid sebagai obyek atau penerima pelajaran. Untuk itu guru harus menjalin hubungan yang harmonis dengan murid agar lebih mudah dalam penyampaian materi pelajaran.

Ketujuh, Seorang pendidik dalam memberikan hadiah harus melihat latar belakang anak didiknya terlebih dahulu. Bila hadiah berupa pensil atau buku diberikan kepada anak orang kaya, maka tentu tujuan pemberian hadiah akan kurang berarti sebagai motivasi baginya. Adapun murid yang dikasihani dan diberi hadiah adalah si miskin yang bajunya kotor dan mukanya masam.

Terhadap anak yang seperti ini guru punya banyak kesempatan untuk membangkitkan semangat mereka yang sudah mati. Salah satu jalan untuk menghidupkan jiwa mereka adalah dengan mengetahui hal ihwal kecenderungan menolong dan membantunya serta memberikan petunjuk dan pengertian kepada mereka dengan penuh kejujuran dan kasih sayang. Sedangkan ganjaran yang berupa hadiah sebagai alat pendidikan tidak demikian. Bukan suatu keharusan, anak yang pandai atas pekerjaan baik akan mendapatkan hadiah dari gurunya. Anak yang pandai dan selalu menujukkan pekerjaan yang baik tidak perlu selalu mendapatkan hadiah.

Kedelapan, Dalam memberikan mukafa'ah atau penghargaan, pendidik jangan mendasarkannya atas keberhasilan siswa dalam prestasinya, sebab akan membuat nilai mukafa'ah sendiri tidak bernilai apa-apa, sementara penghargaan atau mukafa'ah tersebut merupakan kebanggaan atau kekayaan batin yang tidak ternilai harganya.

Kesembilan, Secara ilmiah jika manusia mendapat pujian atau sanjungan, maka ia akan berbesar hati dan akan mempunyai berbagai motivasi untuk dijadikan bahan pertimbangan dalam mengahadapinya dan sering kali berguna bagi perkembangan dirinya. Jadi tidak hanya anak-anak yang membutuhkan pujian, tetapi orang dewasa pun membutuhkannya. 


\section{F. Penutup}

Setelah diuraikan persepsi atau pemikiran-pemikiran Imam al-Ghozali tentang pemberian ganjaran dan hukuman dalam pendidikan, maka dapat diambil kesimpulan sebagai berikut :

1. Menurut Imam al-Ghozali, ganjaran harus diberikan kepada anak didik karena akan membuat anak didik bertambah giat dan semangat dalam meningkatkan prestasinya.

2. Menurut Imam al-Ghozali, pemberian ganjaran hendaknya lebih diprioritaskan, seperti anak dipuji di hadapan orang banyak, ditampilkan di hadapan teman-temannya serta dihadapan orang-orang penting dan berkedudukan, sehingga menjadi motivasi bagi dirinya dan bagi yang lainnya. Sedangkan pemberian hukuman hendaknya dengan cara hubungan timbal balik yang harmonis sehingga antara pendidik dan terdidik tidak ada kerenggangan hubungan, bahkan hubungan tetap harmonis. Pemberian hukuman ini dilakukan setelah melihat jenis dan kuantiotas kesalahan.

3. Imam al-Ghozali memandang bahwa pemberian ganjaran dan hukuman dalam pendidikan dapat dijadikan alat motivasi ekstrinsik terhadap belajar anak, karena tidak semua anak memiliki motivasi instrinsik yang kuat.

4. Menurut Imam al-Ghozali, pemberian ganjaran dan hukuman merupakan metode yang aman bagi pemberian motivasi anak didik dengan batas-batas yang wajar. Mendidik anak dengan cara yang kasar atau dengan paksaan akana mengakibatkan aktivitas atau kerajinannya menurun dan mendorongnya untuk berbuat dusta serta berpura-pura melakukan perbuatanperbuatan baik karena takut mendapatkan hukuman.

5. Bentuk ganjaran dalam pendidikan menurut Imam al-ghozali sangat banyak jenisnya. Namun secara garis besar dapat digolongkan menajdi tiga jenis, yaitu : Pujian, Penghormatan dan Hadiah. Sedangkan bentuk hukuman bisa berupa : Teguran, Peringatan dan Hukuman Fisik.

\section{DAFTAR PUSTAKA}

Al-Ghazālī, Abū Hāmid. (1990). Ihyā 'Ulūm ad-Dīn, Beirut : Dār Ihyā At-Turāts, Arifin, Muhamad. (2003). Ilmu Pendidikan Islam; Tinjauan Teoritis dan Praktis Berdasarkan Pendekatan Interdisipliner. Edisi Revisi.Jakarta : BumiM Aksara.

Athiyah, Abrasyi Muhamad. (1974). Dasar-dasar Pokok Pendidikan Islam, terj. Bustami A. Goni dan Djohar Bahry, (Jakarta : Bulan Bintang, 1974), Cet. 2 
(2003). al-Tarbiyah al-Islāmiyah, Terj.Abdullah Zaky al-Kaaf.

Bandung: Pustaka Setia.

Bukhori, Imam. (1981). Shahīh al-Bukhārī, Beirut : Dār al-Fikr.

Dahlan, Zaini Ahmad. (1970). Riwayat Hidup al-Ghozali. Jakarta : Bulan Bintang.

Darajat, Zakiyah. (1984). Ilmu Pendidikan Islam, Jakarta : Bumi Aksara

Durkheim, Emile. (1990). Moral Education. Terj.Lukas Ginting. Jakarta: Penerbit Erlangga.

Fajar, Malik. (2005). Holistika Pemikiran Pendidikan. Jakarta: Raja GrafindoPersada.

Haqul, M. Atiqul. (2007).SeratusPahlawan Muslim Yang Mengubah Dunia. Yogyakarta :Diglosia.

Khalik, Abdul (1999). PemikiranPendidikan Islam. Yogyakarta :Pustaka Pelajar Offset.

Langgulung, Hasan. (2003). Asas-asas Pendidikan Islam. Jakarta: PT.Pustaka Al-Husna Baru. Cet.Ke-5.

Mustofa. (1997). Filsafat Islam. Bandung : Pustaka Setia

Purwantana, (1991).SelukBelukFilsafat Islam. Bandung : PT. Remaja Rosda Karya.

Purwanto, Muhamad Ngalim. (1995). Ilmu Pendidikan, Teoritis dan Praktis. Bandung: Rosdakarya.

Slamento. (2003). Belajar dan Faktor-faktor yang Mempengaruhinya. Edisi Revisi. Jakarta: Rineka Cipta.

Sirozi, Muhammad. (2003). Agenda Strategis Pendidikan Islam. Yogyakarta: AK

Syadali, Ahmad. (1997). Filsafat Umum. Bandung : Pustaka Setia.

Syalabi, Ahmad. (1984). Sejarah Pendidikan Islam. Bandung : Al-Ma'arif. 